\title{
POTENSI MINUMAN FUNGSIONAL WEDANG UWUH SEBAGAI KONTROL BERAT BADAN DAN KONTROL KADAR GLUKOSA DARAH
}

\section{The Potential of Functional Drink's Wedang Uwuh as Body Weight Control and Blood Glucose Level}

\author{
Harijono, Lulus Mualimin*, Teti Estiasih, Siti Narsito Wulan, Hera Sisca Pramita \\ Departemen IImu dan Teknologi Pangan, Fakultas Teknologi Pertanian, Universitas \\ Brawijaya, Malang, Indonesia, 65145 \\ *Penulis korespondensi, Email: lulus01ali@gmail.com
}

\begin{abstract}
ABSTRAK
Wedang uwuh merupakan minuman tradisional khas daerah Yogyakarta yang telah dilaporkan memiliki aktivitas tinggi antioksidan. Penelitian ini bertujuan untuk optimasi formula bahan herbal kayu secang, jahe, kayu manis, kapulaga dan cengkeh untuk pembuatan wedang uwuh yang mempunyai aktivitas tinggi antioksidan sebagai kontrol berat badan dan kadar glukosa darah. Rancangan percobaan ini menggunakan True Experimental Design: Post Test Only Control Group Design. Hasil dari penelitian menunjukkan bahwa formulasi wedang uwuh mampu sebagai kontrol berat badan dan kadar glukosa darah.
\end{abstract}

Kata kunci: Berat badan, Kadar glukosa darah, Wedang uwuh

\section{ABSTRACT}

Wedang uwuh is a traditional drink from Yogyakarta that has been reported to have high antioxidant activity. This study objective to optimize the formula of herbal ingredients of secang wood, ginger, cinnamon, cardamom and cloves for the making of wedang uwuh which has high antioxidant activity as a body weight control and blood glucose levels. The research design in this experiment uses True Experimental Design: Post Test Only Control Group Design. The results showed that wedang uwuh was able to control body weight and blood glucose levels.

Keywords: Blood glucose level, Mixture design, Wedang uwuh

\section{PENDAHULUAN}

Wedang uwuh merupakan minuman tradisional khas daerah Yogyakarta yang telah dilaporkan memiliki aktivitas antioksidan tinggi. Komponen dari wedang uwuh berupa kayu secang, jahe, kayu manis, kapulaga dan cengkeh (Muchtadi, 2004). Formulasi wedang uwuh selama ini sangat beragam, tetapi peranan kayu secang sangat penting. Jika porsinya terlalu rendah menyebabkan warna wedangnya tidak menarik. Kayu secang mengandung komponen fenolik dengan aktivitas antioksidan tinggi berupa brazilin $\left(\mathrm{C}_{16} \mathrm{H}_{14} \mathrm{O}_{5}\right)$ dan sappanin $\left(\mathrm{C}_{12} \mathrm{H}_{12} \mathrm{O}_{4}\right)$ yang berperan dalam memberikan warna merah (Febriyenti et al., 2018). Secara sensoris, bahan herbal lainnya berperan membentuk flavor. Optimasi formula untuk mencapai tingkat antioksidan yang tinggi sebagai bentuk inovasi untuk pembakuan porsi bahan bakunya diharapkan dapat meningkatkan manfaat dan memperluas penggunaannya 
Minuman kaya antioksidan telah dilaporkan memiliki peran penting dalam mengurangi resiko terjadinya obesitas serta dapat mengontrol kadar glukosa dalam darah. Obesitas terjadi karena penumpukan lemak yang berlebihan akibat ketidakseimbangan antara asupan energi dengan energi yang digunakan dalam waktu yang lama (Foufelle \& Ferre, 2002). Obesitas berkaitan dengan sindroma metabolik. Penderita obesitas sentral lebih berisiko mengalami sindroma metabolik dibandingkan obesitas perifer (Mexitalia et al., 2012). Sindroma metabolik dapat berpotensi sebagai pemicu munculnya penyakit sistemik lain seperti hipertensi, hiperkolesterolemia serta hiperglikemia (Yee et al., 2013). Akumulasi jumlah lemak tubuh yang berlebihan pada penderita obesitas atau kelebihan berat badan (overweight) dapat memicu meningkatnya asam lemak bebas (FFA) yang mengganggu kerja insulin. Hal ini menyebabkan kegagalan absorbsi glukosa ke dalam sel yang mengakibatkan kadar glukosa darah meningkat atau hiperglikemia (Sugiritama at al., 2015).

Penelitian ini bertujuan untuk optimasi formula bahan herbal kayu secang, jahe, kayu manis, kapulaga dan cengkeh untuk pembuatan wedang uwuh yang mempunyai aktivitas tinggi antioksidan sebagai kontrol kadar glukosa darah.

\section{BAHAN DAN METODE}

\section{Bahan}

Bahan wedang uwuh adalah kayu secang, jahe, kapulaga, cengkeh dan kayu manis. hewan coba berupa tikus putih jenis Rattus Norvegicus Strain Wistar dewasa yang berumur 4-5 bulan, berat badan 150-200 gram dengan kondisi sehat yang dibuktikan melalui surat keterangan sehat dari dokter hewan.

Perhitungan jumlah tikus percobaan menggunakan rumus Federer dengan $\mathrm{n}$ merupakan jumlah sampel tiap perlakuan dan p sebagai jumlah perlakuan (Jusman \& Abdul, 2009).

$$
\begin{gathered}
(n-1)(t-1) \geq 15 \\
(n-1)(3-1) \geq 15 \\
2(n-1) \geq 15 \\
n \geq 8
\end{gathered}
$$

Perhitungan di atas menunjukkan bahwa jumlah hewan coba yang akan digunakan sebagai sampel penelitian minimal sebanyak 8 ekor untuk tiap kelompok. Total sampel yang dibutuhkan sejumlah 24 ekor hewan coba.

Jenis bahan kimia yang digunakan aquades, ethanol 96\%, $\mathrm{HCl} 37 \%$ (Merck), $\mathrm{Na}_{2} \mathrm{CO}_{3}$ 7\% (Merck), pati, silica gel, DPPH. Bahan pakan tinggi lemak terdiri dari pati jagung (Maizenaku), kasein basah, tepung kuning telur, dextrin, sukrosa, lemak sapi, CMC, PLA biji asam, multivitamin (Renovit), lisetin. Semua bahan yang digunakan dalam analisis berstandar pro analisis.

\footnotetext{
Alat

Alat yang digunakan adalah timbangan digital (Scout Ohaous), timbangan analitik, magnetik stirer, pipet volume $10 \mathrm{ml}$ dan $1 \mathrm{ml}$, gelas ukur $100 \mathrm{ml}, 50 \mathrm{ml}$ dan $10 \mathrm{ml}$, pipet tetes, beaker glass ukuran $100 \mathrm{ml}, 250 \mathrm{ml}$ dan $500 \mathrm{ml}$, termometer raksa, $\mathrm{pH}$ meter, viskometer, kompor listrik, stopwatch, spektro UV-Vis, panci infusa, tabung reaksi, vortek mixer, kabinet drayer, soxhlet, dekstruktor, buret, labu kjeldahl, labu soxhlet, spatula, botol semprot, corong dan erlenmeyer $250 \mathrm{ml}$. Selain itu digunakan juga blood glucose test meter model AGM-2100 dengan strip glucotest GlucoDr ${ }^{\mathrm{TM}}$ No. 8 (Allmedicus).
} 


\section{Desain Percobaan}

Percobaan ini menggunakan metode True Experimental Design: Post Test Only Control Group Design. Pemilihan objek percobaan RAL (Rancangan Acak Lengkap) dengan 3 kelompok perlakuan dengan rincian sebagai berikut:

Kontrol Negatif (P0) : Tikus normal, diberi pakan Standart AIN 93

Kontrol Positil (P1) : Tikus diberi pakan tinggi lemak hewan + kuning telur

Perlakuan 1 (P2) : Tikus diberi pakan tinggi lemak hewan + kuning telur wedang uwuh disondekan.

\section{Tahapan Penelitian}

Penelitian ini diawali dengan pembuatan wedang uwuh kemudian disonde selama 40 hari perlakuan dengan diberi pakan tinggi kolesterol. Lalu dilakukan pengujian kadar glukosa darah tikus pada hari ke 40.

\section{Metode}

\section{Preparasi Wedang Uwuh}

Pemilihan simplisia kayu secang, jahe, kayu manis, cengkeh dan kapulaga. Masing - masing bahan baku dihaluskan menggunakan blender dan diayak 60 mesh dan didapatkan serbuk simplisia masing-masing bahan dengan komposisi kayu secang $50 \%$, jahe $20 \%$, jahe $25 \%$, kapulaga $3 \%$ dan cengkeh $2 \%$.

\section{Ektraksi Wedang Uwuh}

Bahan sesuai formula diberi air dengan rasio 1:20 (b/v) dan direbus pada suhu $90^{\circ} \mathrm{C}$ selama 5 menit. Pembuatan wedang uwuh mengacu pada (Harborne et al., 1996) .

\section{Prosedur Pembuatan Pakan Tikus Tinggi Lemak dan Kolesterol}

Komposisi pembuatan pakan tinggi kolesterol dengan diet basal dapat dilihat pada Tabel 1 dengan standar pakan mendekati komposisi pakan AIN 93. Setiap formula pakan diberikan kepada setiap ekor tikus pada masing-masing kelompok perlakuan sebanyak 20 gram/ekor/hari. beberapa jurnal menyebutkan bahwa pembuatan pakan tikus biasanya menggunakan 1\% kolesterol untuk dapat dikatakan tinggi kolesterol. Namun pada penelitian ini sumber kolesterol diganti menggunakan lemak hewan dan kuning telur

Tabel 1. Formula Pakan Tikus Percobaan dengan Pakan Standar Modifikasi AIN 93

\begin{tabular}{lcc}
\hline Komposisi Bahan (gram) & $\begin{array}{c}\text { Kel. Tikus Diet } \\
\text { Standart } \\
\text { Normal }\end{array}$ & $\begin{array}{c}\text { Kel. Tikus Diet } \\
\text { Tinggi Lemak } \\
(\text { KOL) }\end{array}$ \\
\hline Tepung Maizena & 367.45 & 336.01 \\
Kasein & 855.49 & 0 \\
Tepung Kuning Telur & 0 & 400 \\
Dekstrin & 122.3 & 111.84 \\
Sukrosa & 78.9 & 72.15 \\
Lemak sapi & 0 & 124.43 \\
CMC & 32.77 & 34.24 \\
Multivitamin & 0 & 32 \\
Lesitin & 2.5 & 0 \\
Ekstrak kasar PLA biji asam & 0 & 0 \\
1)Komposisi pakan mendekati komposisi pakan standar AIN 93 & \\
2)Diet tinggi akan : tinggi tepung kuning telur dan lemak sapi &
\end{tabular}




\section{Dosis Sonde Wedang Uwuh}

Dosis wedang uwuh yang disondekan ke tikus melalui konversi dosis ukuran rata-rata dari manusia $(70 \mathrm{~kg}$ ) ke tikus (200 gram) yaitu sebesar 0.0018 (Laurence dan Bacharah, 1964). Asumsi yang dipakai, berat badan orang Indonesia rata-rata $60 \mathrm{~kg}$ dan orang minum wedang uwuh sebanyak $200 \mathrm{ml}$ per hari. Atas dasar asumsi tersebut maka dosis pemberian minuman wedang uwuh adalah :

$$
\frac{60 \mathrm{~kg} 60 \mathrm{~kg}}{70 \mathrm{~kg} 70 \mathrm{~kg}} \times 200 \mathrm{ml} \times 0,0018=0,308 \mathrm{ml} / \mathrm{KgBB}
$$

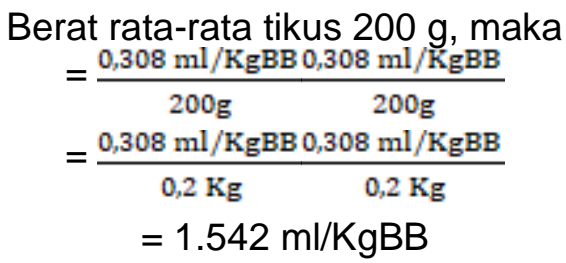

Dosis pemberian wedang uwuh dari $60 \mathrm{Kg}$ berat badan manusia ke $200 \mathrm{~g}$ tikus adalah sebesar $1,542 \mathrm{ml} / \mathrm{KgBB}$. Dosis wedang uwuh yang diberikan kepada tikus akan menyesuaikan dari masing - masing berat badan tikus.

\section{Prosedur Analisis}

Pakan diberikan secara ad libitum berdasarkan acuan formulasi AIN-93. Pemberian pakan dilakukan selama 40 hari, kelompok P0 diberikan pakan standar, kelompok P1 diberikan pakan tinggi lemak dan kelompok P2 diberikan pakan tinggi lemak + wedang uwuh. Masing-masing tikus diberi pakan sebanyak 20 gram. Pada hari ke 39 tikus dipuasakan untuk persiapan pengambilan darah, hari berikutnya dilakukan proses pengambilan darah pada orbital plexus untuk mengetahui kadar glukosa darah tikus yang telah diberi perlakuan selama 40 hari.

Prosedur analisis berat badan adalah dengan menimbang berat badan tikus pada hari pertama sebelum perlakuan dan dilakukan kembali menimbang berat badan tikus secara berkala setiap 7 hari dengan menggunakan timbangan digital merk camry.

\section{Analisis Statistik}

Data hasil penelitian diolah dan dianalisis dengan ragam (ANOVA) dan jika hasil menunjukkan perbedaan maka dilakukan uji lanjut menggunakan uji BNT dengan selang kepercayaan $95 \%$.

\section{HASIL DAN PEMBAHASAN}

\section{Potensi Optimasi Formulasi Minuman Fungsional Wedang Uwuh Sebagai Kontrol Berat Badan dan Kadar Glukosa Darah}

\section{Rerata Konsumsi Pakan}

Nilai rerata konsumsi pakan oleh tikus disajikan pada Gambar 1.

Konsumsi pakan oleh tikus sedikit beragam antar kelompok. Diantara kelompok perlakuan, terbanyak konsumsi dijumpai pada tikus kelompok P1 disusul P0, P2. Berdasarkan hasil analisis ragam menunjukkan bahwa perbedaan jenis kelompok tikus tidak berpengaruh nyata terhadap nilai rerata konsumsi pakan $(\alpha=0,05)$ sehingga semua jenis kelompok tikus memiliki tingkat konsumsi yang hampir sama. 


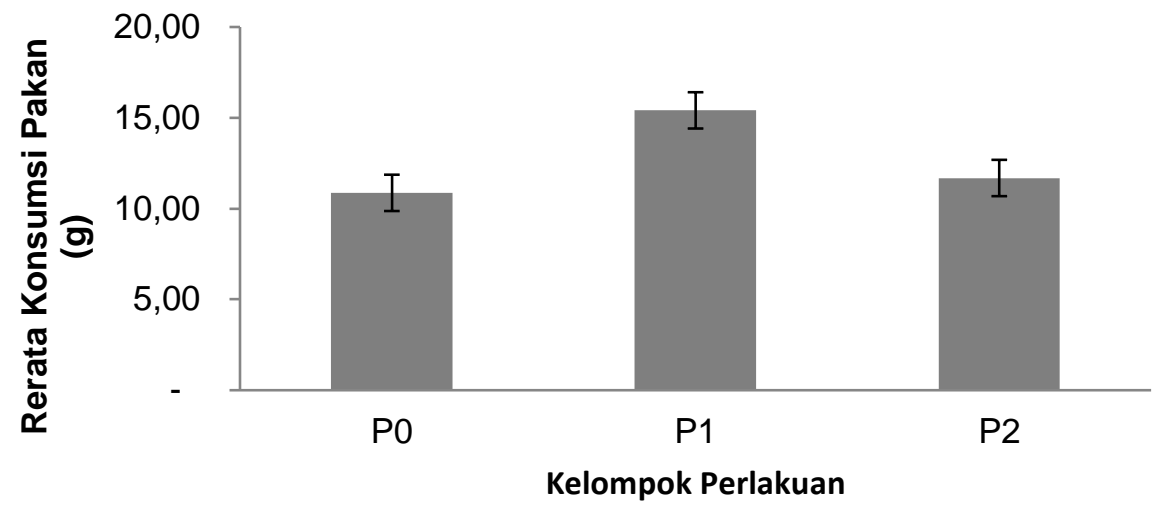

Keterangan: P0 (Tikus dengan pakan standard), P1 (Tikus dengan pakan tinggi lemak), P2 (Tikus dengan pakan tinggi lemak + Uwuh)

Gambar 1. Nilai Rerata Konsumsi Pakan oleh Tikus

Konsumsi pakan kelompok P2 dan P0 memiliki perbedaan yang tidak signifikan. Pemberian sonde wedang uwuh yang kaya antioksidan diduga mengandung beberapa senyawa bioaktif, seperti 4-O-methylsappanol dan protosappanin A (Nagai et al., 1986), protosappanin B (Nagai et al., 1986), protosappanin E, brazilin, brazilein dan caesalpin J (Miyahara et al.,1986), brazilide A (Yang et al., 2015) neosappanone A (Nguyen et al., 2004) caesalpin $\mathrm{P}$, sappanchalcone, 3-deoxysappanone ( $\mathrm{Li}$ et al., 2004). Jahe mengandung senyawa bioaktif gingerol, shagaol dan zingeberone (Babu et al., 2013. Kayu manis memiliki komponen aktif yang disebut cinnamaldehyde (Gul \& Safdar, 2009). kapulaga mengandung beberapa senyawa penting diantaranya D-limonene, 1,8-ceole, terpineol, geraniol, dan $\alpha$ terpinyl asetat (Mehyar et al., 2014) dan cengkeh mengandung senyawa flavonoid, asam hidroksibenzoat, hidroksifenil propen, asam hidroksisinamat, serta terpenoid (Bao et al., 2012).

Menurut Paul et al., (1997), pada makanan mengandung lemak tinggi ditemukan kurang lebih ada 400 senyawa. Sebagian besar di antaranya (220 senyawa) bersifat volatile dan berperan memberikan aroma dan rasa (White, 1991) yang disukai tikus. Kemungkinan hal itu yang menyebabkan nilai rata-rata konsumsi tikus kelompok $\mathrm{P} 1$ lebih tinggi jika dibandingkan tikus pada kelompok lainnya. Peranan antioksidan dalam wedang uwuh justru sebaliknya. Senyawa antioksidan diduga mampu menekan hormon colecitokinin CCK sehingga nafsu makan tikus tetap tinggi (Molan et al., 2007).

\section{Rerata Peningkatan Berat Tikus}

Umumnya tikus sehat memiliki berat antara 200 - $300 \mathrm{~g}$ dan lebih dari itu kemungkinan tikus mengalami obesitas (Hariono, 2006). Grafik perubahan berat tikus dapat dilihat pada Gambar 2. Perubahan berat badan tikus menunjukan keragaman antar kelompok. Berdasarkan hasil ANOVA dan uji BNT kelompok perlakuan menghasilkan perbedaan yang nyata $(\alpha=0.05)$ terhadap kenaikan rerata berat tikus (Tabel 2 ). 


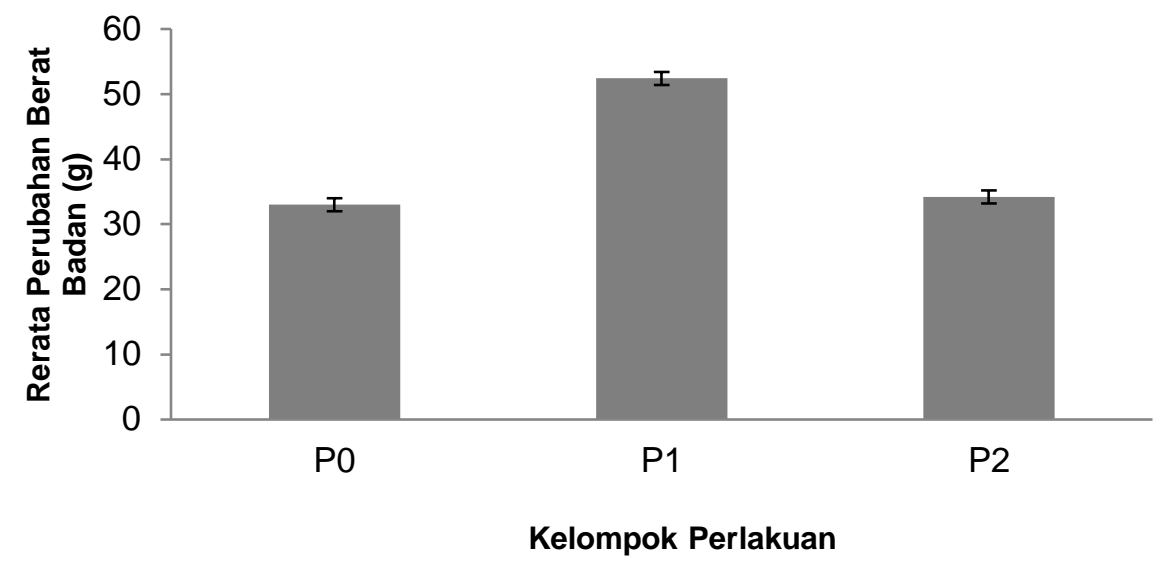

Keterangan: P0 (Tikus dengan pakan standard), P1 (Tikus dengan pakan tinggi lemak), P2 (Tikus dengan pakan tinggi lemak + Uwuh)

Gambar 2. Grafik Perubahan Berat Tikus

Tabel 2. Efek Perlakuan terhadap Perubahan Berat Tikus

\begin{tabular}{cccccc}
\hline $\begin{array}{c}\text { Kelompok } \\
\text { Perlakuan }\end{array}$ & $\begin{array}{c}\text { Berat Tikus } \\
\text { Awal }\end{array}$ & $\begin{array}{c}\text { Berat Tikus } \\
\text { Akhir }\end{array}$ & Perubahan & $\begin{array}{c}\text { Pengaruh } \\
\text { Pakan } \\
\text { Terhadap } \\
\text { Perubahan BB } \\
\text { (g pakan/ g BB) }\end{array}$ & $\begin{array}{c}\text { BNT } \\
5 \%\end{array}$ \\
\hline P0 & $244.6 \pm 19.35$ & $268.2 \pm 46.66$ & $33.0^{\mathrm{b}}$ & 3.04 & 7.65 \\
P1 & $256.8 \pm 35.08$ & $318.4 \pm 41.76$ & $52.4^{\mathrm{a}}$ & 3.40 & \\
P2 & $251.8 \pm 46.79$ & $295.2 \pm 32.44$ & $34.2^{\mathrm{b}}$ & 2.93 & \\
\hline
\end{tabular}

Keterangan: Pemberian Notasi yang berbeda menunjukkan perbedaan yang nyata $(\alpha=0.05)$

Tikus pada kelompok P1 mengalami peningkatan berat badan yang paling tinggi dibandingkan dengan kolompok lainnya. Hal ini membuktikan bahwa pemberian wedang uwuh dapat mengurangi terjadinya overweight. Sindroma metabolik diawali pada metabolisme lemak, yang melibatkan banyak proses uptake, transport dan penyimpanan lemak. TG (trigliserida) dalam makanan berlemak yang dikonsumsi kemudian dipecah menjadi free fatty acid dan 2-monoasil gliserol. Pemecahan terjadi di dalam lumen usus halus oleh enterocyte melalui mekanisme difusi pasif dengan bantuan transporter spesifik seperti CD36. Kolesterol juga di uptake oleh enterocyte dengan bantuan transporter spesifik yaitu NPC1L1 (Altmann, 2004) dan (Davis et al., 2004). Di dalam enterocyte, kolesterol diubah menjadi kolesterol ester dan asam lemak bebas, sedangkan 2-monoasil gliserol dirakit menjadi triasilgliserol (TAG). Keduanya dijadikan satu dikemas bersama fosfolipid dan apolipoprotein B48 dalam bentuk kilomikron, yang selanjutnya diedarkan ke dalam jaringan limfatik (Pan \& Hussain, 2012; Rozana, 2016). Hati mensintesis lipoprotein yang kaya TAG, yang disebut lipoprotein densitas sangat rendah (VLDL). Senyawa ini meningkatkan postprandial untuk memproduksi garam empedu ketika makanan yang mengandung lemak dipecah kembali menjadi asam lemak dan monoasil gliserol oleh garam empedu. Perakitan hampir sama dengan sintesis kilomikron tetapi yang membedakan adalah protein struktural VLDL yaitu apolipoprotein B100 dan sisanya setelah VLDL diubah menjadi garam empedu akan diubah menjadi yaitu lipoprotein densitas menengah (IDL) dan low density lipoproteins (LDL) (Klop et al., 2012).

Kadar TG yang tinggi dalam darah akan menyebabkan nekrosis dalam jaringan hati dan menyebabkan penurunan sensitivitas insulin. Ketika insulin mengalami penurunan sensitivitas maka kadar gula (dalam darah) akan meningkat. Kadar gula yang meningkat akan 
menstimulasi faktor transkripsi mRNA PPARY yaitu C/EBPb, C/EBPd, EBF1 dan KLF5 untuk mengaktifkan PPARY (Arsa, 2016) dan (Horton \& Tan, 2004). PPARY merupakan cotranskripsi yang mengkode basa nitrogen dari DNA adipogenesis (Rosen et al., 2009). Jika PPARY aktif akan terjadi adipogenesis kemudian akumulasi lemak meningkat yang menyebabkan kenaikan berat badan.

Antioksidan memiliki kemampuan menekan faktor transkripsi PPARY (Gumieniczek, 2003). Antioksidan dalam wedang uwuh mampu menekan co-faktor transkripsi PPARY. Akibatnya adipogenesis dapat ditekan. Penambahan berat badan tikus tetap terjadi tetapi bukan karena tertimbunnya lemak melainkan oleh lean body mass yang bertambah. Selain itu senyawa fenolik memiliki kemampuan membentuk komplek pada sisi aktifnya dengan beberapa enzim pencernaan sehingga mampu mengurasi penyerapan zat makanan.

\section{Kadar Glukosa Darah Puasa (GDP)}

Pengaruh perlakuan pakan terhadap kadar glukosa darah (post-test) tikus percobaan disajikan pada Gambar 3.

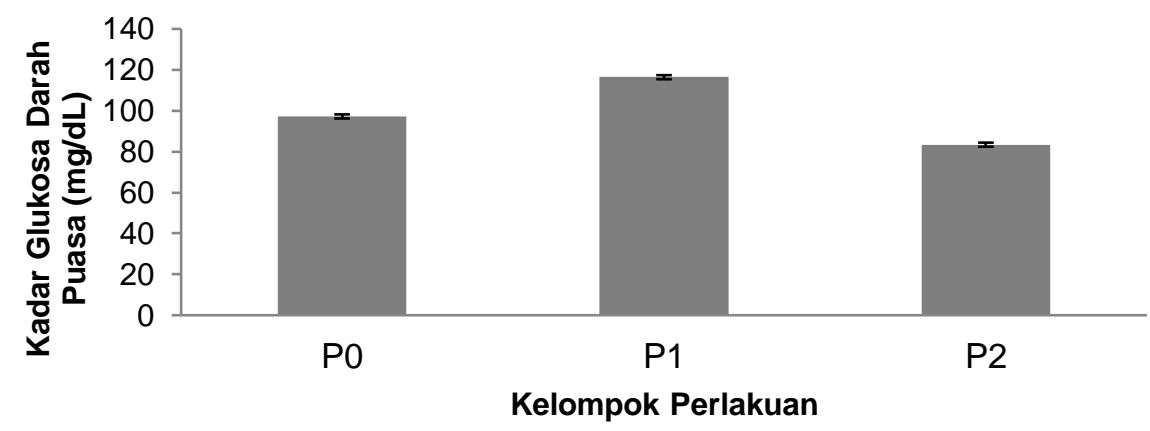

Keterangan: P0 (Tikus dengan pakan standard), P1 (Tikus dengan pakan tinggi lemak), P2 (Tikus dengan pakan tinggi lemak + Uwuh)

Gambar 3. Pengaruh Perlakuan Pakan terhadap Kadar Glukosa Darah (post-test) Tikus Percobaan

Pemberian pakan tinggi lemak dan kolesterol pada tikus bertujuan untuk mengkondisikan tikus untuk mengalami keseimbangan energi positif kronik sehingga tikus mengalami obesitas dan terjadi metabolik syndrome (Eckel et al., 2005). Pengkondisian obesitas dengan pemberian pakan tinggi lemak dan kolesterol menyebabkan jaringan adiposa tidak mampu menyimpan TAG sehingga terjadi lipid overflow (Taghibiglou et al., 2002) yang kemudian disirkulasi melalui pembuluh darah dan dibawa ke liver. Darah yang tinggi TAG, asam lemak bebas dan VLDL menyebabkan metabolisme liver terganggu (Foufelle \& Ferre, 2002). Jika metabolisme liver terganggu akibatnya sensitivitas insulin juga menurun dan kadar glukosa dalam darah akan meningkat. Kadar GDP tikus dalam percobaan dapat dilihat pada Gambar 3.

Kadar GDP beragam antar tikus dari kelompok perlakuan yang berbeda, tetapi nilainya paling tinggi pada tikus kelompok P1. Pakan tinggi lemak dan kolesterol diduga menyebabkan terjadinya lipid overflow sehingga kadar TAG dan asam-asam lemak dalam darah meningkat dan mengalami sindrom metabolik. Sindrom metabolik diawali pada metabolisme lemak, yang melibatkan banyak proses uptake, transport dan penyimpanan lemak. TG (trigliserida) dalam makanan berlemak yang dikonsumsi akan dipecah menjadi asam lemak bebas \& 2monoasilgliserol. Pemecahan terjadi di dalam lumen usus halus oleh enterocyte melalui mekanisme difusi pasif dengan bantuan transporter spesifik seperti CD36. Kolesterol juga di uptake oleh enterocyte dengan bantuan transporter spesifik yaitu NPC1L1 (Altmann, 2004) dan (Davis et al., 2004). Di dalam enterocyte, kolesterol diubah menjadi kolesterol ester dan 
asam lemak bebas, sedangkan 2-monoasilgliserol dirakit menjadi triasilgliserol (TAG). Keduanya dijadikan satu dikemas bersama fosfolipid dan apolipoprotein B48 dalam bentuk kilomikron, yang selanjutnya diedarkan ke dalam jaringan limfatik (Pan \& Hussain, 2012). Hati mensintesis lipoprotein yang kaya TAG, yang disebut lipoprotein densitas sangat rendah (VLDL). Senyawa ini meningkatkan postprandial untuk memproduksi garam empedu ketika makanan yang mengandung lemak dipecah kembali menjadi asam lemak dan monoasil gliserol oleh garam empedu. Pembentukan kolesterol baik (HDL) hampir sama dengan mekanisme sintesis kilomikron tetapi yang membedakan adalah protein struktural VLDL yaitu apolipoprotein B100 dan sisanya setelah VLDL diubah menjadi garam empedu akan diubah menjadi yaitu lipoprotein densitas menengah (IDL) dan low density lipoproteins (LDL) (Klop et al., 2012). Kadar TG yang tinggi dalam darah akan menyebabkan nekrosis dalam jaringan hati dan menyebabkan penurunan sensitivitas insulin. Ketika insulin mengalami penurunan sensitivitas maka kadar gula (dalam darah) akan meningkat.

Tikus pada kelompok P2 memiliki kadar GDP yang lebih rendah daripada tikus kelompok P1. Pemberian wedang uwuh hasil formulasi bahan herbal yang tinggi aktivitas antioksidan mampu berperan dalam mengontrol KGD pada tikus percobaan kelompok P2. Minuman herbal dari kayu secang memberikan efek purifikasi pada darah dan bersifat anti diabetes. Kandungan brazilin dalam kayu secang juga dapat menstimulasi glucose transport pada sel 3T3-L1. Peningkatan glucose transport dapat meningkatkan uptake glukosa pada otot dan jaringan adipose (Kim et al., 1995). Gingerol pada jahe meningkatkan sekresi insulin yang distimulasi glukosa dengan mengaktifkan sekresi insulin yang dimediasi GLP-1 pathway dan mengatur eksositosis insulin granul dan meningkatkan penyerapan glukosa pada otot rangka dengan meningkatkan ekspresi membran GLUT4 (Samad et al., 2017). Menurut Adisakwattana (2011), kayu manis mampu menghambat pembentuk enzim $\alpha$-glukosidase dan menurunkan kadar glukosa darah postprandial.

\section{SIMPULAN}

Pemberian wedang uwuh pada tikus memberikan pengaruh signifikan pada penurunan kadar glukosa pada tikus obesitas. Pemberian wedang uwuh juga efektif dalam mengontrol peningkatan berat tikus dan kadar glukosa darah pada tikus percobaan.

\section{DAFTAR PUSTAKA}

Altmann, S. W. (2004). Niemann-Pick C1 Like 1 Protein Is Critical for Intestinal Cholesterol Absorption. Science, 303(5661), 1201-1204. https://doi.org/10.1126/science.1093131

Arsa, M. (2016). Proses Pencoklatan (Browning Process) Pada Bahan Pangan.

Bao, L.-M., Eerdunbayaer, Nozaki, A., Takahashi, E., Okamoto, K., Ito, H., \& Hatano, T. (2012). Hydrolysable Tannins Isolated From Syzygium Aromaticum: Structure of a New C-Glucosidic Ellagitannin and Spectral Features Of Tannins with a Tergalloyl Group. Heterocycles, 85(2), 365-381. https://doi.org/10.3987/COM-11-12392

Davis, H. R., Zhu, L., Hoos, L. M., Tetzloff, G., Maguire, M., Liu, J., Yao, X., lyer, S. P. N., Lam, M.-H., Lund, E. G., Detmers, P. A., Graziano, M. P., \& Altmann, S. W. (2004). Niemann-Pick C1 Like 1 (NPC1L1) Is the Intestinal Phytosterol and Cholesterol Transporter and a Key Modulator of Whole-body Cholesterol Homeostasis. Journal of Biological Chemistry, 279(32), 33586-33592. https://doi.org/10.1074/jbc.M405817200

Eckel, R. H., Grundy, S. M., \& Zimmet, P. Z. (2005). The metabolic syndrome. The Lancet, 365(9468), 1415-1428. https://doi.org/10.1016/S0140-6736(05)66378-7

Febriyenti, F., Suharti, N., Lucida, H., Husni, E., \& Sedona, O. (2018). Karakterisasi dan Studi Aktivitas Antioksidan dari Ekstrak Etanol Secang (Caesalpinia sappan L.). Jurnal Sains 
Farmasi \& Klinis, 5(1), 23. https://doi.org/10.25077/jsfk.5.1.23-27.2018

Foufelle, F., \& Ferre, P. (2002). New perspectives in the regulation of hepatic glycolytic and lipogenic genes by insulin and glucose: a role for the transcription factor sterol regulatory element binding protein-1c. Biochemical Journal, 366(2), 377-391. https://doi.org/10.1042/bj20020430

Gul, S., \& Safdar, M. (2009). Proximate Composition and Mineral Analysis of Cinnamon. Pakistan Journal of Nutrition, 8(9), 1456-1460. https://doi.org/10.3923/pjn.2009.1456.1460

Gumieniczek, A. (2003). Effect of the new thiazolidinedione-pioglitazone on the development of oxidative stress in liver and kidney of diabetic rabbits. Life Sciences, 74(5), 553-562. https://doi.org/10.1016/j.lfs.2003.03.004

Harborne, J. B., Sudiro, I., Padmawinata, K., \& Niksolihin, S. (1996). No Title. https://opac.perpusnas.go.id/DetailOpac.aspx?id=577450\#

Hariono, B. (2006). Efek Pemberian Plumbum (Timah Hitam) Anorganik Pada Tikus Putih (Rattus norvegicus). Jurnal Sain Veteriner, 24(1), 125-134. https://doi.org/https://doi.org/10.22146/jsv.367

Horton, E. S., \& Tan, M. H. (2004). Introduction. International Journal of Clinical Practice, 58, 1-2. https://doi.org/10.1111/j.1368-504X.2004.00327.x

Klop, B., Wouter Jukema, J., Rabelink, T. J., \& Castro Cabezas, M. (2012). A physician's guide for the management of hypertriglyceridemia: the etiology of hypertriglyceridemia determines treatment strategy. Panminerva Medica, 54(2), 91-103. http://www.ncbi.nlm.nih.gov/pubmed/22525564

Li, W. ., Zheng, H. ., Bukuru, J., \& De Kimpe, N. (2004). Natural medicines used in the traditional Chinese medical system for therapy of diabetes mellitus. Journal of Ethnopharmacology, 92(1), 1-21. https://doi.org/10.1016/j.jep.2003.12.031

Mehyar, F., Al-Isamil, K. M., Al-Ghizzawi, H. M., \& Holley, R. A. (2014). Stability of Cardamom ( Elettaria cardamomum ) Essential Oil in Microcapsules Made of Whey Protein Isolate, Guar Gum , and Carrageenan. Journal of Food Chemistry, 79(10), 1939-1949. https://doi.org/10.1111/1750-3841.12652

Mexitalia, M., Anam, M., Uemura, A., \& Yamauch, T. (2012). KOMPOSISI TUBUH DAN KESEGARAN KARDIOVASKULER YANG DIUKUR DENGAN HARVARD STEP TEST DAN 20M SHUTTLE RUN TEST PADA ANAK OBESITAS. Media Medika Indonesia, 46(1), 12-19. https://ejournal.undip.ac.id/index.php/mmi/article/view/4200

Nagai, M., Nagumo, S., Lee, S.-M., Eguchi, I., \& Kawai, K.-I. (1986). Protosappanin A, a novel biphenyl compound from Sappan Lignum. Chemical and Pharmaceutical Bulletin, 34(1), 1-6. https://doi.org/10.1248/cpb.34.1

Nguyen, M. T. T., Awale, S., Tezuka, Y., Tran, Q. Le, \& Kadota, S. (2004). Neosappanone A, a xanthine oxidase $(\mathrm{XO})$ inhibitory dimeric methanodibenzoxocinone with a new carbon skeleton from Caesalpinia sappan. Tetrahedron Letters, 45(46), 8519-8522. https://doi.org/10.1016/j.tetlet.2004.09.107

Pan, X., \& Hussain, M. M. (2012). Gut triglyceride production. Biochimica et Biophysica Acta (BBA) - Molecular and Cell Biology of Lipids, 1821(5), 727-735. https://doi.org/10.1016/j.bbalip.2011.09.013

Paul, S., Mittal, G. S., \& Chinnan, M. S. (1997). Regulating the use of degraded oil/fat in deepfat/oil food frying. Critical Reviews in Food Science and Nutrition, 37(7), 635-662. https://doi.org/10.1080/10408399709527793

Rosen, E., Eguchi, J., \& Xu, Z. (2009). Transcriptional targets in adipocyte biology. Expert Opinion on Therapeutic Targets, 13(8), 975-986. https://doi.org/10.1517/14728220903039706

Rozana. (2016). Respon Suhu dan Bentuk Irisan Terhadap Laju Pengeringan dan Mutu Manisan Mangga (Magnifera Indica L.). Institut Pertanian Bogor (IPB). 
Taghibiglou, C., Rashid-Kolvear, F., Van Iderstine, S. C., Le-Tien, H., Fantus, I. G., Lewis, G. F., \& Adeli, K. (2002). Hepatic Very Low Density Lipoprotein-ApoB Overproduction Is Associated with Attenuated Hepatic Insulin Signaling and Overexpression of Proteintyrosine Phosphatase 1B in a Fructose-fed Hamster Model of Insulin Resistance. Journal of Biological Chemistry, 277(1), 793-803. https://doi.org/10.1074/jbc.M106737200

Yang, Y., Cui, S. W., Gong, J., Guo, Q., Wang, Q., \& Hua, Y. (2015). A soy proteinpolysaccharides Maillard reaction product enhanced the physical stability of oil-in-water emulsions containing citral. Food Hydrocolloids, 48, 155-164. https://doi.org/10.1016/j.foodhyd.2015.02.004 